\title{
PHARMACOLOGICAL CORRECTION OF COGNITIVE DISORDERS IN EXPERIMENTAL NEURODEGENERATION CAUSED BY 2 TYPE DIABETES MELLITUS*
}

\author{
O. G. Kmet, N. D. Filipets, T. I. Kmet, \\ T. I. Hrachova, Y. M. Vepriuk, K. V. Vlasova \\ Higher State Educational Establishment of Ukraine \\ "Bukovinian State Medical University", Chernivtsi, Ukraine \\ kmet.olga@bsmu.edu.ua
}

\begin{abstract}
Neurodegeneration diseases (NDD) are progressing neuropsychological disorders. Diabetes mellitus (DM) plays an important role among its causes. In spite of the lack of sufficient amount of scientifically based evidences which are indicative of a close relation between $\mathrm{DM}$ and neurodegeneration, there is an opinion that this pathology produces a negative effect on the cerebral metabolism, promotes cerebral atrophy and accelerates brain aging. Decrease of cognitive functions is known to be one of the main complications of DM. At the same time this disease is one of the risk factors promoting development of Alzheimer's disease - one of the most spread diseases of neurodegenerative character [1].
\end{abstract}

High energy requirements make the brain especially sensitive to glucose metabolism. Deficiency of glucose availability and mitochondrial dysfunction are well known signs of brain aging, and they are especially intensified in case of NDD, such as Alzheimer's disease. At the same time, in case of Alzheimer's disease much lower levels of glucose metabolism and pathological processes are found associated with decreased sensitivity of cerebral neurons to insulin.

Insulin resistance decreases glucose metabolism resulting in hyperphosphorylation of tau-protein promoting formation of neurofibrillary glomeruli (protein accumulation in a modified form) and NDD progress. Moreover, neu-

* The work was performed in accordance with the planned research of the department of Pathological Physiology of the Higher State Educational Establishment of Ukraine «Bukovinian State Medical University» on the topic: "New methodical approaches to the pathogenetic treatment of dysfunction of the proximal nephron in conditions of the development of dysregulation pathological process of renal and non-renal origin» (state registration number 0118U001193).

Institution, which financed the research: Ministry of Health of Ukraine.

The authors assume responsibility for the published work.

The authors guarantee absence of competing interests and their own financial interest when carrying out the research and writing the article.

The manuscript was received by the editorial staff 5.04.2019. 
rodegeneration is intensified by DM, and by hyperglycemia in particular [2].

One of the main causes of memory deterioration is not only hyperglycemia but insufficient amount of sugar in the brain, where its deficiency is found in case of DM-2, which is evidenced by experimental and clinical investigations [3]. The majority of anti-diabetic agents produce a positive effect in case of DM, though an optimal glycemia level is achieved in the minority of patients, which requires additional pharmacological agents. Moreover, existence of «hyperglycemic» memory gives the grounds to suggest that the majority of patients can lose their sensitivity to control an optimal glucose level after a long period of its uncontrolled increase [4].

Nowadays an active search of effective pharmacological agents is being conducted concerning preventive therapy and treatment of NDD. It is worth noting that with glucose metabolism it remains a functional cycle of gamma-aminobutyric acid (GABA) [5, 6]. In addition, dysglycemia uses the functional activity of GABA, a universal neurotransmitter of the central nervous system (CNS), due to which there is a constant inhibition and development, energy supply, cognitive functions [7].
Considering the above, investigation of the efficacy of carbacetam, as a new GABA modulator, seems to be topical [8] under conditions of development of neurodegenerative changes in case of DM.

The circulating (systemic) and tissue (cerebral) renin-angiotensin system (RAS) participate in pathogenesis of cognitive disorders. RAS blockers, that is, angiotensin converting enzyme inhibitors (ACEI), are known to decrease hippocampus apoptosis in case of cerebral ischemia, and improve spatial learning and memory considerably [9]. Though nowadays ACEI are considered to be as means of prevention and treatment of DM complications, their role as GABA modulators in case of development of central diabetic neurodegeneration is not determined exactly. The neuroprotective efficacy of ACEI in scopolamine-induced CNS damage was experimentally established [10], which led to the use of ACEF enalapril under the combination of diabetes and central neurodegeneration in our study.

Objective: to assess efficacy of pharmacological correction of cognitive disorders by carbacetam, GABA modulator, and enalapril, RAS blocker, in case of experimental neurodegeneration caused by type $2 \mathrm{DM}$.

\section{MATERIALS AND METHODS}

The experiments were conducted on male rats $0,18-0,20 \mathrm{~kg}$ of the body weight kept under conditions of natural light, temperature and air humidity according to vivarium standards. The research was performed in accordance with European Convention for the Protection of Vertebrate Animals used for Experimental and other Scientific Purposes (Strasburg, 1986).

Type 2 DM model was simulated by means of intraperitoneal (i/p) injection of streptozotocin (STZ) in the dose of $30 \mathrm{mg} / \mathrm{kg}$ on the citrate buffer $(\mathrm{pH}=4,5)$ given to rats kept on high-fat diet during 30 days, with free access to fructose solution $(200 \mathrm{~g} / \mathrm{L})$ [11]. The control group of rats kept on standard forage and free access to water was given citrate buffer i/p. Reproduction of type $2 \mathrm{DM}$ was evidenced on the $7^{\text {th }}$ day after STZ injection by means of detection of glucose concentration in the blood plasma on empty stomach. Rats with hyperglycemia lower than $10 \mathrm{mmol} / \mathrm{L}$ were excluded from the experiment.
On the $11^{\text {th }}$ week after STZ injection the rats were divided into three groups by means of randomized method: I - with i/p administration of carbacetam in the dose of $5 \mathrm{mg} / \mathrm{kg}$; II - with i/p administration of enalapril in the dose of $1 \mathrm{mg} / \mathrm{kg}$; III — with administration of physiological solution (saline).

The control group of rats during the whole period of correction (14 days) received saline only.

Cognitive ability of rats was assessed by the indices of tests «open field» and «the conditional reflex reaction of passive avoidance» (CRPA) [12-14]. Anti-amnestic activity (AA) was calculated by means of Butler formula [15]: $\mathrm{AA}=(\Delta \mathrm{LPP}-\Delta \mathrm{LPC}) /(\Delta \mathrm{LPI}-\Delta \mathrm{LPC}) \times 100(\%)$, $\Delta \mathrm{LP}$ - difference of latent period (LP) of entrance to a dark camera during studying and reproduction of CRPA for the examined specimen $\triangle \mathrm{LPP}$; simulated pathology $(\triangle \mathrm{LPC})$; the control group ( $\triangle \mathrm{LPI})$. 
The results were statistically processed by means of Student t-criterion. At the same time, Mann-Whitney criterion was used, which showed similar results. Transformations were considered to be reliable with $\mathrm{p} \leq 0,05$.

\section{RESULTS AND THEIR DISCUSSION}

To verify manifesting type $2 \mathrm{DM}$ we have examined glycemic dynamics. The glucose level in DM rats on the $10^{\text {th }}$ week after Stz administration was $11,99 \pm 1,562 \mathrm{mmol} / \mathrm{L}$, against $4,87 \pm 0,713 \mathrm{mmol} / \mathrm{L}$ in the control $(p<0,05)$. Attention is paid to the fact that in comparison with the group without correction, on the $14^{\text {th }}$ day of carbacetam and enalapril administration reliable changes of the parameter were not found. Thus, glucose concentration in untreated rats was $12,01 \pm 1,654 \mathrm{mmol} / \mathrm{L}$, in the group with carbacetam $-9,94 \pm 0,932 \mathrm{mmol} / \mathrm{L}$, in rats receiving enalapril $-10,92 \pm 0,976 \mathrm{mmol} / \mathrm{L}$.

The «open field» test of mnestic functions analysis showed that in rats with DM type 2 LP adaptation increased on $53.4 \%$ compared with the control group (Table 1). In rats receiving carbacetam this index $24,1 \%$ reduced, and with enalapril administration it did not differ from the value of simulated pathology. Since the characteristics of the test are light open space and new surroundings, certain exertion and behavioral changes of rats manifested by increased LP of adaptation in rats with type 2 DM are indicative of an increased degree of risk: confusion, fear, disorientation in strange surroundings. At the same time, LP decrease, this interval of immobility, was peculiar for rats with type $2 \mathrm{DM}$ after carbacetam injection, which is indicative of activation of natural adaptive reactions to unusual conditions.

Motor activity of rats with type $2 \mathrm{DM}$ reduced: the number of crossed squares 37,9\% decreased. After carbacetam administration this index $33,9 \%$ and $31,9 \%$ increased - after enalapril administration, which is indicative of improvement of horizontal motor activity due to inhibition of psychological anxiety of rats with neurodegeneration of diabetic genesis.

Table 1

Effect of carbacetam and enalapril on the motor, oriented-learning and emotional activity of rats with type 2 diabetes mellitus in "open field» test, $M \pm m$

\begin{tabular}{|c|c|c|c|c|}
\hline Indices & Control $(n=7)$ & $\begin{array}{c}\text { Diabetes } \\
\text { mellitus }(n=7)\end{array}$ & $\begin{array}{c}\text { Diabetes } \\
\text { mellitus }+ \\
\text { carbacetam } \\
(\mathbf{n}=7)\end{array}$ & $\begin{array}{c}\text { Diabetes } \\
\text { mellitus }+ \\
\text { enalapril } \\
(n=7)\end{array}$ \\
\hline \multicolumn{5}{|c|}{ Period of immobility } \\
\hline $\begin{array}{c}\text { Latent period } \\
\text { (adaptation time), c }\end{array}$ & $10,43 \pm 1,51$ & $16,00 \pm 1,00^{*}$ & $12,14 \pm 0,90 * *$ & $14,71 \pm 1,11^{*}$ \\
\hline \multicolumn{5}{|c|}{ Motor activity } \\
\hline $\begin{array}{c}\text { Number of crossed } \\
\text { squares }\end{array}$ & $23,00 \pm 1,83$ & $14,29 \pm 1,11^{*}$ & $19,14 \pm 1,22^{* *}$ & $18,86 \pm 1,22^{* *}$ \\
\hline \multicolumn{5}{|c|}{ Orientation-learning activity } \\
\hline Positions & $9,29 \pm 1,11$ & $3,57 \pm 0,79^{*}$ & $8,29 \pm 1,11^{* *}$ & $9,00 \pm 1,16^{* *}$ \\
\hline Openings & $12,57 \pm 0,98$ & $7,00 \pm 0,82^{*}$ & $10,29 \pm 1,11^{* *}$ & $9,00 \pm 0,82^{*}$ \\
\hline \multicolumn{5}{|c|}{ Emotional reactions } \\
\hline Grooming & $7,86 \pm 0,69$ & $3,14 \pm 0,69 *$ & $5,57 \pm 0,82 * * * *$ & $6,14 \pm 0,69 * *$ \\
\hline Urination & $4,14 \pm 0,69$ & $2,00 \pm 0,58^{*}$ & $1,71 \pm 0,76$ & $4,00 \pm 0,58^{* *}$ \\
\hline Fecal bolus & $3,71 \pm 0,76$ & $1,14 \pm 0,38^{*}$ & $1,86 \pm 0,69$ & $3,43 \pm 0,54^{* *}$ \\
\hline
\end{tabular}

Reliability:

* in comparison with the control group;

** in comparison with the group of rats with type $2 \mathrm{DM}$. 
The variant of oriented-learning behavior of rats is frequency of their upright postures (rising on hind legs) and examined holes. In comparison with the control group in rats with type $2 \mathrm{DM}$ the frequency of upright $65,6 \%$ decreased and the amount of the examined holes $-44,3 \%$. The obtained results are indicative of activation of inhibition processes in the CNS of rats with DM. Under carbacetam effect the above indices 2,3 and 1,5 times increased respectively. Meanwhile, enalapril administration caused 2,5 times increase of upright motor activity only compared with the rats from the group of simulated pathology.

The results obtained give evidence about ability of both drugs to reduce anxiety level and improve cognitive activity of rats with DM. At the same time, carbacetam improves both horizontal and vertical motor activity, and enalapril - vertical one only. One of the important characteristics in behavior of experimental animals in «open field» is emotional reactions (Table 1). Grooming - cosmetic behavior a sign of both comfort and stressful situation, was characterized by $60 \%$ decreased number of washing in rats with DM. Under carbacetam effect grooming sign $77 \%$ increased, and after enalapril administration it increased to $96 \%$ compared with the value in rats with DM. Further analysis of vegetative behavior did not find changes in the amount of urination and fecal boluses with carbacetam use, which in general it enables to suggest the absence of its important effect on the emotional level of rats with DM under conditions of the experiment. At the same time, enalapril administration promoted increase of urination and fecal boluses 2 and 3 times respectively in comparison with the simulated rats.

Assessment of cognitive ability according to CRPA test showed that in the control rats a stable reflex to pain stimulation by electric current was formed (Table 2). Thus, comparison of LP duration of I and II series determined increased time interval 2,8 times as much 1 day after the first entrance of rats into a dark camera. On the $14^{\text {th }}$ day this interval 2,5 times increased compared with the indices of I group. It should be noted that in comparison with the indices of II group LP 14 days later decreased reliably as well. Though, reliable difference with the index of I series was indicative of CRPA maintenance in the group of control during all the periods of the experiment.

Further analysis of results was indicative of CRPA formation after electric-painful stimulation of rats with type $2 \mathrm{DM}$ (Table 2). 1 day later since the moment of electric current stimulation LP 57,8 \% increased. Though, deterioration of memory of rats and CRPA inhibition on the $14^{\text {th }}$ day after type 2 DM modeling was evidenced by $35,1 \%$ reduced LP of entrance into a dark camera in comparison with the indices of II series. At the same time, dynam-

Table 2

\section{Effect of carbacetam and enalapril on the latent period of entrance to a dark camera of rats with type 2 diabetes mellitus in CRPA test, $M \pm m$}

\begin{tabular}{|c|c|c|c|c|}
\hline \multirow{8}{*}{$\begin{array}{c}\text { Latent period } \\
\text { of entrance } \\
\text { into the dark } \\
\text { unit, } c\end{array}$} & \multicolumn{4}{|c|}{ Before carbacetam administration, I series } \\
\hline & Control, $\mathrm{n}=7$ & \multicolumn{3}{|c|}{ Diabetes mellitus, $\mathrm{n}=21$} \\
\hline & $61,14 \pm 3,98$ & \multicolumn{3}{|c|}{$62,47 \pm 2,59$} \\
\hline & \multicolumn{4}{|c|}{1 day after carbacetam administration, II series } \\
\hline & Control, $\mathrm{n}=7$ & $\begin{array}{l}\text { Diabetes mellitus, } \\
\mathrm{n}=7\end{array}$ & $\begin{array}{c}\text { Diabetes mellitus + } \\
\text { carbacetam, } \mathrm{n}=7\end{array}$ & $\begin{array}{c}\text { Diabetes mellitus + } \\
\text { enalapril, } \mathrm{n}=7\end{array}$ \\
\hline & $170,71 \pm 1,80^{*}$ & $98,57 \pm 6,08^{\#}$ & $123,14 \pm 6,91^{\# * * *}$ & $119,14 \pm 4,98^{\#, * *}$ \\
\hline & \multicolumn{4}{|c|}{14 days after carbacetam administration, III series } \\
\hline & $154,14 \pm 6,52^{*}$ & $64,00 \pm 6,25^{\#}$ & $118,29 \pm 7,39^{\#}, * *$ & $107,00 \pm 7,98^{\#}, * *$ \\
\hline
\end{tabular}

\section{Reliability:}

* compared with the control of I series;

* compared with the control of II, III series;

** compared with simulated type 2 DM of II, III series. 


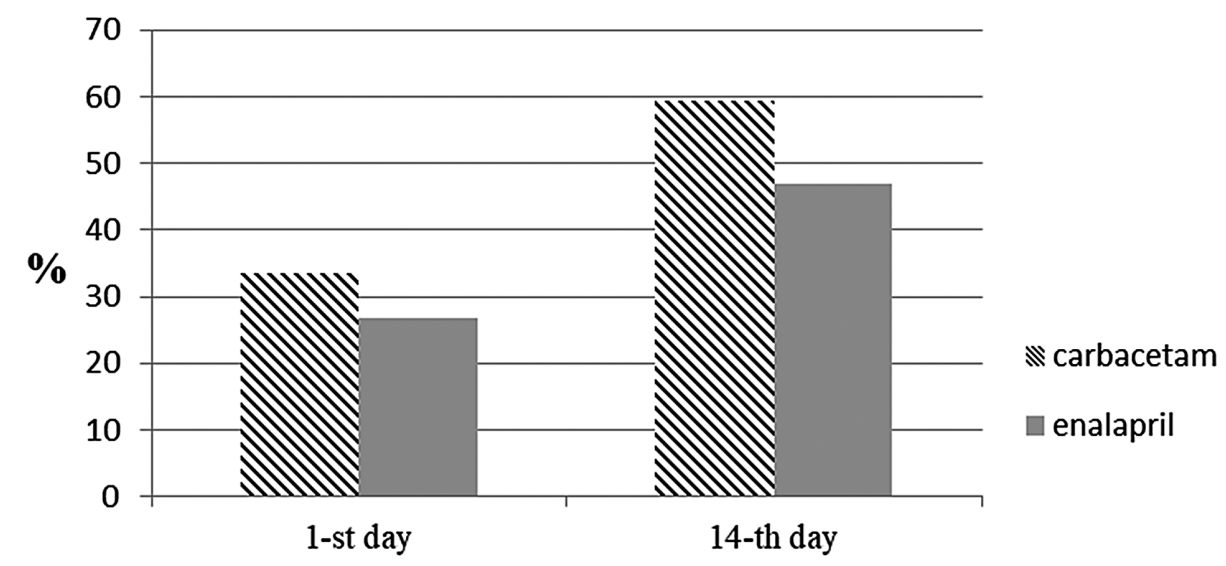

Fig. 1. Anti-amnestic activity of rats with type 2 diabetes mellitus in the conditional reflex reaction of passive avoidance on the 1 st and $14^{\text {th }}$ day after carbacetam and enalapril administration.

ics of changes in II and III series was characterized by 42,3 and $58,5 \%$ decreased LP in comparison with appropriate control indices. It proved the fact of a progressing deterioration of memory in rats with type $2 \mathrm{DM}$.

1 day after carbacetam and enalapril administration LP of the entrance into a dark camera remained higher than that of the rats with type $2 \mathrm{DM}$ of II series, and the difference was 25 and $21 \%$ respectively. The obtained results were indicative of the ability of the examined pharmacological agents to improve cognitive activity under the experiment conditions. The results of III series were indicative of probability of this suggestion. 14 days later after carbacetam and enalapril administration the dynamics of LP changes was characterized by increase of the indices 1,8 and 1,7 times as much in comparison with untreated rats.

AA analysis by Butler formula determined that the parameters under carbacetam effect are higher than those under enalapril effect both on the $1^{\text {st }}$ and more on the $14^{\text {th }}$ day (Fig. 1). At the same time, a considerable increase of AA in both groups on the $14^{\text {th }}$ day of correction is indicative of an increasing effect after repeated (course) administration of GABA and ACEI modulator.

The obtained data concerning anti-amnestic action are caused by the mechanism of action of the drugs. Nootropic action of carbacetam can be associated with the effect on GABA-ergic system [14], which modulation of the condition promotes improvement of cerebral circulation and bioenergetic processes of the brain.
Confirmation of this assumption is the information [16] about the existence in the walls of the vessels of the system of synthesis and degradation of GABA, which plays a significant role in the regulation of cerebral circulation: expansion of cerebral vessels, increased blood flow, oxygenation and improvement of brain energy. In addition, carbacetam is modulated by GABA $_{\mathrm{A}}$-receptors - regulators of permeability of chlorine channels in the CNS [12]. When the intracellular chlorine anion increases, hyperpolarization occurs, neural communication and synchronization of neuronal populations are improved, and cognitive processes are activated [17]. It is possible that the corrective effect of carbacetam on the prooxidantantioxidant balance [8] is one of its protective mechanisms in the neurodegenerative processes of the CNS caused by type 2 diabetes.

Improvement of memory, cognitive and integral thinking activity against the ground of enalapril administration was caused by inhibition of excessive activity under conditions of hyperglycemia effect and angiotensin II, which is a neurotoxin in its excessive amount [18]. Also, given the data on the regulatory role of cerebral RAS in learning and memory [19], improvement of cerebral blood supply is a leading mechanism of resistance to neurodegeneration. It is worth noting that the effect of RAS blockers is realized through peroxisome proliferatoractivated receptor-Y (PPARY receptors), which are the central regulation of insulin and glucose metabolism, which suppresses the progression of neurodegeneration, mediated by hyper- 
phosphorylation and tau phosphorylation is a mechanism of the neuroprotective action of enalapril [20].

Therefore, the analysis of the results indicates the presence of rehabilitative effects of carbacetam and enalapril on cognitive function in rats in the absence of glucose-lowering effects in experimental neurodegeneration modeled on type 2 diabetes.

\section{CONCLUSIONS}

1. Behavior of rats with type 2 diabetes mellitus in "open field» test after carbacetam $(5 \mathrm{mg} / \mathrm{kg})$ and enalapril $(1 \mathrm{mg} / \mathrm{kg})$ administration for 14 days is characterized by decrease of the latent period of «immobility», increased motor, oriented-learning activity, and is indicative of a prevailing action of carbacetam on reduction of anxiety level, improvement of adaptation and cognitive reactions.

2. After carbacetam administration for 14 days reduced grooming index is not resumed and the frequency of vegetative reactions - fecal boluses and defecations - is not changed, which is indicative of the lack of carbacetam effect on emotional level of rats with diabetes mellitus compared with enalapril improving emotional condition of rats.

3. Increase of latent period of entrance into a dark camera on the $1^{\text {st }}$ and $14^{\text {th }}$ day of correction reflects maintenance of the conditional reflex reaction of passive avoidance to electric painful stimulation, and respectively improvement of cognitive ability of rats with diabetes mellitus, mostly after administration of carbacetam than enalapril.

4. In both groups with correction increased anti-amnestic activity of rats was determined by means of Butler formula with dynamic increase of the index, mainly under carbacetam effect on the $14^{\text {th }}$ day of the experiment.

\section{REFERENCES}

1. Vinod N. Gerontol Geriatric Stud. 2018; 3(2): 1-14. doi: 10.31031/GGS.2018.03.000556.

2. Yin F, Sancheti H, Patil I, Cadenas E. Free Radic Biol Med. 2016; 100: 108-122. doi: 10.1016/j.freeradbiomed. 2016.04.200

3. Kalchenko VI, Wovk MV, Rodik RV, Yarosh AK. Pharmacol Drug Toxicol. 2016; 6(51): 21-31.

4. Poltorak VV, Gorshuns'ka MJu, Krasova NS. Mezhdunar Jendokrinol Zhurn. 2014; 5(6): 15-21.

5. Hertz L. Front Endocrinol. 2013; 4(59): 1-16. doi: 10. 3389/fendo.2013.00059.

6. Panov A, Orynbayeva Z, Vavilin V, Lyakhovich V. Biomed Res Int. 2014; 2014: 472459. doi: 10.1155/2014/ 472459.

7. Li Y, Sun H, Chen Z, at al. Front Aging Neurosci 2016; 8(31): 1-12. doi: 10.3389/fnagi.2016.00031.

8. Kozak DV. Shpytal'na hirurgija. Zhurn im. L. Ja. Koval'chuka. 2014; 1(65): 40-42.

9. Huang X, Lu G, Li G, et al. Front Neurosci. 2017; 11: 11. doi: 10.3389/fnins.2017.00359.

10. Jawaid T, Jahan S, Kamal MJ. Adv Pharm Technol Res. 2015; 6(3): 130-135. doi:10.4103/2231-4040.161514.

11. Rybak VA, Maloshtan LM, Poltorak VV, Krasova NS. Pharmacol Drug Toxicol 2015; (42):76-81.
12. Apryatin SA, Shipelin VA, Trusov NV, et al. Physiol Rep. 2019; 7(4): 13987. doi: 10.14814/phy2.13987.

13. Martinez-Dнаz JA, Garcia LI, Hernandez ME, ArandaAbreu GE. Neurologia. 2015; 30(7): 407-415. doi.org/ 10.1016/j.nrleng.2014.03.003.

14. Kmet OG, Ziablitsev SV, Filipets ND, et al. Arch Balkan Med Union. 2019; 54(1): 124-129. doi.org/10.31688/ABMU. 2019.54.1.17.

15. Deiko RD, Strigol SJ, Kolobov OO, Bezditko NV. Pharmacol Drug Toxicol. 2015; 6(46): 19-27.

16. Trujeque-Ramos $\mathrm{S}$, Castillo-Rolyn D, Galarraga E, et al. Front Neurosci. 2018. 1-15. doi:10.3389/fnins.2018.00345.

17. Cheng Zhou, Jin Liu, Xiang-Dong Chen. World J Crit Care Med. 2012; 1(3): 80-93. doi: 10.5492/wjccm.v1.i3.80.

18. Ramsey CP, Tansey MG. Exp Neurol. 2014; 256: 126132. doi: 10.1016/j.expneurol.2013.05.014.

19. Almeida-Santos F, Kangussu AM, Moreira FA, et al. Protein Peptide Lett. 2017; 24(9): 841-853. doi: 10.2174/ 0929866524666170822120258.

20. Luppi M, Hitrec T, Di Cristoforo A, et al. Front Neuroanat. 2019; 13(57): 1-doi: 10.3389/fnana.2019.00057. 


\title{
PHARMACOLOGICAL CORRECTION OF COGNITIVE DISORDERS IN EXPERIMENTAL NEURODEGENERATION CAUSED BY 2 TYPE DIABETES MELLITUS
}

\author{
O. G. Kmet, N. D. Filipets, T. I. Kmet, T. I. Hrachova, Y. M. Vepriuk, K. V. Vlasova \\ Higher State Educational Establishment of Ukraine \\ "Bukovinian State Medical University», Chernivtsi, Ukraine \\ kmet.olga@bsmu.edu.ua
}

A progressive increase of complications of type $2 \mathrm{DM}$ makes the problem very important for clinical and fundamental medicine. In particular, neurodegenerative processes in case of type 2 DM aggravate the course of the disease, change a usual life rhythm, and are a valuable cause of high rates of disability and lethality. Deterioration of cognitive functions is one of the main complications of diabetes. In certain literary sources inhibitors of angiotensin-transforming enzyme are considered as the means to prevent and treat complications of diabetes mellitus. Their role as modulators of gama-aminobutyric acid with development of central diabetic neurodegeneration is not completely determined yet.

Therefore, the objective of the study is to assess efficacy of pharmacological correction of cognitive disorders by carbacetam, a GABA modulator, and enalapril, a RAS blocker, in case of experimental neurodegeneration caused by type $2 \mathrm{DM}$.

Changes of the cognitive functions under carbacetam and enalapril effect in nonlinear laboratory albino male rats with neural degeneration under conditions of type 2 diabetes mellitus simulated by streptozotocin and high fat diet are studied. The cognitive ability was assessed by behavioral reactions of rats in the tests "open field» and «the conditional reflex reaction of passive avoidance» by Butler formula.

Behavior of rats with type 2 diabetes mellitus after administration of carbacetam and enalapril showed of cognitive functions in the groups. At the same time, carbacetam was found to possess better correcting effect on adaptation, cognitive reactions and anti-amnestic activity, while enalapril improved emotional condition of the rats mostly. Analysis of anti-amnestic properties found higher values of the parameters on the $14^{\text {th }}$ day than on the $1^{\text {st }}$ day of correction, which is indicative of the efficacy of a course administration of carbacetam and enalapril under conditions of neural degeneration stipulated by type $2 \mathrm{DM}$.

Key words: type 2 diabetes mellitus, neurodegeneration, carbacetam, enalapril, cognitive ability of rats.

\section{ФАРМАКОЛОГІЧНА КОРЕКЦІЯ КОГНІТИВНИХ ПОРУШЕНЬ ПРИ ЕКСПЕРИМЕНТАЛЬНІЙ НЕЙРОДЕГЕНЕРАЦІЇ, ЗМОДЕЛЬОВАНОЇ ЦУКРОВИМ ДІАБЕТОМ 2 ТИПУ}

Кметь О. Г., Філіпець Н. Д., Кметь Т. І., Грачова Т. І., Вепрюк Ю. М., Власова К. В.

Вищий державний навчальний заклад України

"Буковинський державний медичний університет", л. Чернівиі, Украӥна

kmet.olga@bsmu.edu.ua

Прогресивне зростання чисельності ускладнень цукрового діабету 2 типу робить проблему значущою для клінічної та фундаментальної медицини. Зокрема, нейродегенеративні процеси при цукровому діабеті 2 типу обтяжують перебіг захворювання, змінюють звичайний життевий ритм, є вагомою причиною високих показників інвалідизації та летальності. Зниження когнітивних фуннцій є одним із основних ускладнень діабету. 3 літературних джерел відомо, що інгібітори ангіотензинперетворювального ферменту розглядаються як засоби профілактики і лікування ускладненнях цукрового діабету, їх роль, як і модуляторів гама-аміномасляної кислоти, при розвитку центральної діабетичної нейродегенерації ще остаточно не визначена.

Тому метою роботи е оцінка ефективності фрармакологічної корекції когнітивних порушень модулятором гама-аміномасляної кислоти карбацетаму і блокатором ренін-ангіотензинової системи еналаприлом при експериментальній нейродегенерації, спричиненої цукровим діабетом 2 типу.

Досліджено зміни когнітивних функцій під впливом карбацетаму та еналаприлу у нелінійних лабораторних білих щурів самців із нейродегенерацією за умов цукрового діабету 2 типу, змодельованого стрептозотоцином і високожировою дієтою. Когнітивну здатність оцінювали за поведінковими реакціями щурів у тестах «відкрите поле», «умовного рефлексу пасивного уникнення» та за фрормулою Баттлера.

Оцінка поведінки у щурів із ЦД 2 типу показала покращення стану когнітивних фрункцій у групах із введенням карбацетаму та еналаприлу. Водночас мав місце переважний корегувальний вплив карбацетаму на адаптаційні, пізнавальні реакції та антиамнестичну активність, тоді як еналаприл більшою мірою покращував емоційний стан щурів. Аналіз антиамнестичних властивостей виявив більші значення показників на 14-ту, ніж на 1-шу добу корекції, що вказуе на едективність курсового введення карбацетаму та еналаприлу за умов нейродегенерації зумовленої ЦД 2 типу.

К л юч о в і слов а: цукровий діабет 2 типу, нейродегенерація, карбацетам, еналаприл, когнітивна здатність щурів. 


\section{ФАРМАКОЛОГИЧЕСКАЯ КОРРЕКЦИЯ КОГНИТИВНЫХ НАРУШЕНИЙ ПРИ ЭКСПЕРИМЕНТАЛЬНОЙ НЕЙРОДЕГЕНЕРАЦИИ, СМОДЕЛИРОВАННОЙ САХАРНЫМ ДИАБЕТОМ 2 ТИПА}

Кметь О. Г., Филипец Н. Д., Кметь Т. И., Грачева Т. И., Вепрюк Ю. М., Власова К. В.

Выссшее государственное учебное заведение Украины

"Буковинский государственный медицинский университет», г.Черновиь, Украина kmet.olga@bsmu.edu.ua

Прогрессивный рост численности осложнений сахарного диабета 2 типа делает проблему значимой для клинической и фундаментальной медицины. В частности, нейродегенеративные процессы при сахарном диабете 2 типа отягощают течение заболевания, меняют обычный жизненный ритм, являются весомой причиной высоких показателей инвалидизации и летальности. Снижение когнитивных функций является одним из основных осложнений диабета. Из литературных источников известно, что ингибиторы АПФ рассматриваются как средства профилактики и лечения осложнениях сахарного диабета, их роль, как и модуляторов гамма-аминомасляной кислоты, при развитии центральной диабетической нейродегенерации еще окончательно не определена.

Поэтому целью работы является оценка эфффективности фрармакологической коррекции когнитивных нарушений модулятором гамма-аминомасляной кислоты карбацетамом и блокиратором ренин-ангиотензиновой системы эналаприлом при экспериментальной нейродегенерации, вызванной сахарным диабетом 2 типа.

Исследованы изменения когнитивных функций под влиянием карбацетама и эналаприла в нелинейных лабораторных белых крыс самцов с нейродегенерации при сахарном диабете 2 типа, смоделированного стрептозотоцином и высокожировой диетой. Когнитивную способность оценивали по поведенческим реакциями крыс в тестах «открытое поле», «условного редлекса пассивного избегания» и по формуле Баттлера.

Оценка поведения у крыс с СД 2 типа показала улучшение состояния когнитивных функций в группах с введением карбацетаму и эналаприла. В то же время имел место преимущественное корректирующий влияние карбацетаму на адаптационные, познавательные реакции и антиамнестическое активность, тогда как эналаприл в большей степени улучшал эмоциональное состояние крыс. Анализ антиамнестическое свойств обнаружил большие значения показателей к 14 , чем на 1-е сутки коррекции, указывает на эффективность курсового введения карбацетаму и әналаприла в условиях нейродегенерации обусловленной СД 2 типа.

К л юче в ые с лов а : сахарный диабет 2 типа, нейродегенерации, карбацетам, эналаприл, когнитивная способность крыс. 